\section{Luftalarm over København juli 1940}

Afjournalist Vilh. Bergstrom (1886-1966)

\section{Udgivers forbemarkning}

Forfatter og kriminalreporter ved Politiken Vilhelm Bergstrom og hans dagbog 1939-45 er tidligere prosenteret $i$ Magasin fra Det Kongelige Bibliotek 2004, Nr. 2. Yderligere kan nu henvises til Vilhelm Bergstrom: En Borger i Danmark under Krigen. Dagbog 19391945, 1-2, 2005.

Nedenfor gengives et hidtil delvis undgivet uddrag af dagbogen fra juli 1940, hvor Bergstrom skildrer sin oplevelse af de forste luftalarmer i Kobenhavns historie.

De i dagbogen mest omtalte personer er: Elsa: Bergstroms hustru; Tusse/Ritta: Bergstroms datter; Nash: C. Nash Hendriksen, Bergstoms narmeste kollega på Politiken; Nielsen: Bernhard Nielsen: Bergstroms anden normeste kollega pa bladet.

Udeladelser i dagbogen er markeret med ... Det indfojede $i$ [] er af udgiveren, ligesom alle noter.

\section{Indledning}

Kobenhavn kom forste gang ud for en luftalarm den 7 .juli $1940 \mathrm{kl}$. 2.29. Alarmen varede blot 16 minutter, og der var ikke tale om et luftangreb. Alligevel kom den dato til at satte skel $i$ kobenhavnernes dagligdag. Selv om de siden verdenskrigens udbrud i september 1939 gradvist var blevet forberedt $p a$, at luftrummet over Danmark kunne blive krigsskueplads og siden april 1940 havde indstillet sig $p a ̊ a$, at England kunne valge at bombe tyske mail $i$ Danmark, så havde de endnu ikke provet den oplevelse at skulle styrte til narmeste beskyttelsesrum og klumpe sig sammen under umage forhold, mens der blev skudt over byen. Selve oplevelsen var ny og bragte meget kontant bevidstheden om, at der trods alt var en verdenskrig $i$ gang, på narmeste hold. Oplevelsen af den på en gang vakkede og lammede by er ikke ofte skildret i litteraturen, maske fordi den senere forekom så ofte, at den horte med til de dagligdags trivialiteter, det ikke blev regnet for vard at gore noget serligt ud af.

For Vilhelm Bergstrom, der havde sat sig for at vare verdenskrigens kronikor, var det absolut et nyt fanomen, som han beskaftigede sig sarligt med. Han registrerede bade omgivelsernes og sine egne reaktioner pà de otte alarmer, som juli 1940 bod Kobenhavn pà, ligesom han var interesseret $i$ organiseringen af hele melde-og alarmsystemet. Sidstnaunte interesse bragte bl.a. det artige forhold frem, at en overbetjent for spog havde trykket på alarmknappen og derved uden grund havde jaget hele Kobenhavns befolkning i kalderen. Det var sket om natten til den 23. juli kl. 2.16, og klokken var blevet 2.47 for luftvarnschef Dahl-Jensen kom tilstede og fik blast alarmen af. Det var en form for spog, som de hundredetusinder af berorte ikke fik besked om.

Månedens sidste alarm indtraf den 30. juli, hvorefter der gik så lang tid, for der igen blev luftalarm, at mange nåede at glemme, hvordan det havde varet at have luftalarm. De udeblevne alarmer skyldtes ikke, at de engelske overflyuninger ophorte, men at kriterierne for at ivarksatte alarm blev skarpet. Neste alarm var forst et trekvart air senere, 23. april 1942, og siden forekom de hyppigere og regelmassigt lige til krigens slutning. Kun i to tilfalde var Kobenhavn selv målet under alarmerne, det var ved det engelske bombardement af B \& W27. januar 1943 og ved bombardementet af "Shellhuset"21. marts 1945. Det kunne befolkningen dengang af gode grunde 
ikke vide, så hver luftalarm måtte og skulle tages alvorligt, selv om det forholdsvis hurtigt blev en rutine, og det var starkt fristende at blive liggende i sin seng, når "der nu nok heller ikke skete noget." For at modvirke bl.a. ten-denserne til denne afslappelse eller "slov hed" overfor alarmerne var husvagtordningen blev organiseret $i$ efterairet 1939. Husvagter-ne havde ansvaret for, at beboerne i alle ejendomme kom $i$ beskyttelsesrum, nair alarmen lod. Bergstrom havde $i$

\section{Juli. (Søndag)}

Saa skete det endelig i Nat. Sirenerne lød, og vi blev jaget i Kælderen. Det var en forbandet Historie, men - ikke helt uden Spænding.

Klokken var 2 1 1 2 , da Elsa hev og sled $\mathrm{i}$ mig for at faa mig vaagen. "Sirenerne lyder!" sagde hun. "Naa, gør de det," svarede jeg velvilligt og vendte mig om paa den anden Side. Hvis jeg overhovedet paa det Tidspunkt har haft en Gnist af en Tanke i min Hjerne, saa har jeg formodentlig tænkt, at det var en af de sædvanlige "tekniske Fejl." Omsider fik Elsa trukket saa meget Liv i mig, at jeg blev klar over, at det var et virkeligt Faresignal. Uhu-Uhu, trak det smerteligt frem og tilbage. Det lød forbandet, men betydelig mindre gennemtrængende end jeg havde tænkt mig. Mens jeg kom i Tøjet, havde Elsa sammen vanskelige Omgang med at faa Tusse vaagen. Da det endelig gik op for Tusse, hvad der var los, blev hun helt ude af sig selv. Hun løb op og ned ad Gulvet og kunde ikke finde sine Bukser. Elsa bevarede Kontenancen, og jeg selv følte egentlig ikke andet end Ubehaget ved at blive revet ud af min gode Søvn - og saa det let komiske ved at skulde ned i en Kælder. Men Sirenen hujede formanende, og det var mig ikke mindst juli 1940 for langst presenteret husvagtordningen for laserne af Politiken og skrevet om den i sin dagbog, men forst nu kunne han på forste händ se den i funktion. Som det vil fremgå, var der forskellige begyndervanskeligheder, ligesom dagbogen godt afspejler de talrige og nasten i alle tilfalde urigtige rygter om, hvorfor der var luftalarm. Der var i juli 1940 i intet tilfalde tale om bombardementer $i$ Kobenhavn.

John T. Lauridsen

om at gøre at faa Tusse i Sikkerhed. Saa tav Sirenen. Men nu ringede det paa Døren. Det var en af Husvagterne, der alarmerede. Da han blev klar over, at vi var i Live gik han opefter for at pine paa de andre Ringeapparater. Et Sted i Opgangen skal [han] have faaet en meget uvenlig Modtagelse af en søvnig Herre. Imidlertid var vi kommen i Kludene. Elsa tog vore nødvendige Papirer, som hun i Forvejen havde liggende i en stor Konvolut. Hun sørgede for, at jeg fik en Klapstol med mig. Selv tog hun Køkkenstolen, og saa entrede hele Familien ned ad den smalle Køkkentrappe, Tusse tavs og bleg og rystende over hele Kroppen. Mørklægningslamperne lyste kun svagt paa Trappen. Vi hørte Ure ogsaa paa de andre Trappegange i det store Kompleks. ${ }^{1}$ I Forvejen var vi bleven formanede til at bevare Roen af Overhusvagten for øvrigt den sure Herre, som Husvagten havde vækket. Samme Overhusvagt - jeg kender ham ikke - havde med høj Stemme raabt flere Gange i Gaarden: "Bevar Roen! Bevar Roen!" Der var da forøvrigt heller ingen, der gik fra Koncepterne, om end naturligvis alle var nervøse. Nede i Kældrene var der allerede forsamlet en lille Snes Mennesker, flest Damer. En af dem var i Natdragt. En anden, min Kone sagde en køn 
ung Dame, havde faaet naaet at pudse Facaden, saa mærkeligt det lyder, eftersom vi alle sammen var nede paa mindre end nogle Minutter. Halvdelen havde været saa forsynlige at tage Stole med. Da jeg kom ned, sagde jeg "God Morgen!" og var i det samme klar over det komiske heri, men paa den anden Side, hvad skulde man sige. Der blev mumlet et Godmorgen igen, og saa henfaldt alle til Tavshed. Tusse krøb op paa Elsas Skød og sad og rystede af. Selv anbragte jeg mig i en mørk Krog, jeg skulde ikke frem i Lyset. Jeg følte mig som en Ugle, og en meget søvnig Ugle. Hvert Øjeblik gabede jeg. Jeg ved ikke, om det irriterede nogle, eller fyldte andre med Sympati for jeg kunde ikke faa $\varnothing_{j}$ nene op. Vicevært Flensborg kom ind og forkyndte, at Dørene i det store Kompleks af Kælderrum, der stod til vores Raadighed, skulde være aabne, da vi ellers risikerede at blive spærret inde, hvis det hele ramlede sammen. Det var aabenbart Flensborg en Fornøjelse at gøre Herskaberne lidt forskrækkede. Om det lykkedes ved jeg ikke, men der begyndte at komme lidt Samtale igen om de nærmeste Ting. Kældrene var forresten bleven gjort pænt ryddelige. De var udluftet. Der var intet af den gamle Stank. Men der var, da Dørene kom op, en forbandet Gennemtræk. Jeg blev nødt til at humme mig ud i Lyset. Vi var, som anført, ikke saa mange Mennesker i Kælderen. De fleste Husbeboere var aabenbart paa Landet. Vor kælder er ogsaa offentlig Tilflugtsrum. Men der har nok ikke været ret mange Mennesker paa Gaden, for jeg saa ingen "Uvedkommende." Der blev talt om en Cyklist, som man havde set smide Cyklen og bene mod et eller andet Tilflugtsrum. Kaffehandleren som ellers er saa fuld af Narrestreger, var mærkværdig tavs. Han var vistnok mellem de staaende. Værten havde ganske vist sat nogle Stole ned i Rummet, men det var høje Barstole, og dem skulde ingen have noget af at røgle sig op paa. Jeg tænkte paa, at nu var hele Byen i Bevægelse. Alle har travlt med at søge Kældrene, lige fra de Kongelige paa Amalienborg til Klædesamler Peddersen i en mørk Sidegade. Alle var vi ude for at redde Livet. Om der da kom nogen Flyvemaskiner igennem. Vi lyttede, men kunde ikke høre en Lyd. Ved Midnatstid havde der derimod været et vældigt Træk af tyske Maskiner - de fløj lavt og lavede et stort Spektakkel - Der havde nok allerede paa det Tidspunkt været Alarm ude i Landet. Maaske var Kampen nu i vild Gang. Damen i Nattøjet, som stod op, mente ikke, at hun behøvede nogen Stol, for det vilde vel neppe vare saa længe. Det var et Haab, hun udtalte, men hun fik Ret. Efter at vi havde været et Kvarter i Kælderen, lød den lange ensartede Tone som varslede, at nu var Faren ovre. Og saa luskede vi op alle sammen. Vi havde imidlertid glemt at tage Køkkendørsnøglen af. Elsa maatte om til Hoveddøren. Imens stod Tusse og jeg og ventede. Tusse var endnu meget betaget. Dertil kom, at hun var bleven tissetrængt af al den Nervøsitet. Vi kiggede gennem Vinduet ud i Gaarden. Det var begyndt at lysne. Vi hørte Uroen af de mange Mennesker paa Trapperne. Døre blev aabnet og slaaet i. Omsider blev vor egen Dør aabnet af Elsa indvendig fra. Jeg var lidt i Tvivl om, hvorvidt jeg skulde klæde mig af igen, for der kunde jo meget snart komme en ny Flyveralarm, men Elsa erklærede, at hun kunde ikke sove med Tøjet paa, og [saa] bestemte jeg mig ogsaa til at klæde mig af. Jeg sagde, at hun skulde ringe ud til sin Moder for at berolige hende. Telefonen var imidlertid afbrudt. Antagelig befandt Damerne paa Centralen sig endnu i Kælderen. Tusse var ængstelig og vilde have Lys. Lidt efter fandt jeg paa at det vilde være nok saa godt, at lade Stuen oplyse af den gryende Dag. Vi laa saa i Halvlyset og snak- 
kede sammen. Først faldt Tusse hen, snart efter Elsa. Klokken var omkring 3, da vi kom op fra Kælderen, men endnu ved 5 Tiden laa jeg vaagen. Det var den sædvanlige $\mathrm{Hi}$ storie. Naar jeg bliver vækket ved en Historie fra Bladet, kan jeg heller ikke sove...

\section{Juli. (Mandag)}

Vi sov godt og fast til kl. 8. Der var i og for sig ikke meget at staa op efter. Det regnede. Vi gratulerede os selv til at have faaet Lov til at sove uafbrudt uden at skulle i Kælderen. Det maa man nu til at være glad for. Paa den indirekte Maade kan der efterhaanden skabes en Del Glæder. Mens jeg sad og syslede med mit Klipperi, ringede Næsh. Han fortalte om Fødselsbesværlighederne ved Artiklen om Luftalarmen. Den udenrigsministerielle Censur, altsaa Kontorchef Eskelund, havde forlangt, at Artiklen ikke maatte være foruroligende for Folk. Den maatte heller ikke sige noget om Flyvere og den Slags. Alt det havde man rettet sig efter. Men da han saa ogsaa forlangte, at Artiklen skulde være enspaltet, saa protesterede Priemé. ${ }^{2} 400$ Linjer enspaltet, det vil se ud ad Helvede til. Saa bøjede Censuren sig. Jeg sagde til Næsh:

"Man skulde ikke tro, at Eskelund nogensinde havde været Journalist." I hvert Fald havde han glemt det grundigt. Saa satte jeg mig til at klippe igen. Vi skal hen i Haven og spise Frokost paa Resterne af Aftensmaden i Gaar. Da det stadig regner, bliver vi nødt til at tage Regntøjet paa.

Det blev en udmærket Frokost, selv om det var paa Rester. Der var ogsaa en Rest i Snapseflasken. Elsa gik i Gang med den store Opvask, og Tusse var paa Festpladsen sammen med Tove og legede i et af Tombolateltene. Selv hyggede jeg paa Divanen. Jeg blev jaget op af en let, men behagelig Slummer ved en væmmelig snerrende Lyd i Luften. Jeg rejste mig over Ende. Jo, min
Sandten det var Sirenerne, der lød. Tusse kom farende rystende over hele Kroppen. Elsa fandt Tøjet frem, og afsted for hun med Tusse, mens jeg laaste og stængte. Jeg mødte Fru Rasmussen ude paa Havegangen. Hun var rødsprængt i Ansigtet af Nervøsitet. ”De har vel ikke set, hvilken Vej, min Kone er gaaet?" spurgte jeg. Hun sank en Klump og pegede mod Hovedindgangen. I skarp Gangart gik jeg videre. Det smaaregnede, men jeg havde taget min svære Regnfrakke paa. Sirenerne, som skal kalde i 2 Minutter, var holdt op at lyde. Himlen var graa over det hele, men saa meget fredelig ud. Udenfor paa Gaden saa jeg paa lang Afstand Elsa og Tusse. De saa ogsaa mig, og Elsa ventede. De befandt sig lige ved Brandstationen paa Kløvermarksvej. Langs den ene Side af Pladsen foran Stationen er nedlagt et vældigt Jernbetonrør, som er gravet halvt ned i Grunden og oventil dækket med et tykt Lag Jord. Ved Nedgangen til dette solide Rør stod et Par Brandfolk og vinkede. Vi gik ned ad nogle Trin og passerede en svær Panserdør. Vi drejede en Omgang til venstre og befandt os i Rørets Indre. Det var halvanden Mandshøjde i Diameter. Langs Siderne var Træbænke. Der sad allerede et halvt Hundrede Mennesker. Og dog var der god Plads i den øverste Ende. Deroppe stod en Brandmand og sørgede for Luftfornyelse. Det gav en Lyd, som i høj Grad foruroligede Tusse. Hun rystede over hele Kroppen og forlangte at blive anbragt mellem Elsa og mig, og saa klyngede hun sig til os begge to. Nogle Lamper lyste nødtørftigt op. Den, der var nærmest os, gik et Øjeblik ud. Folk i Nabolaget kunde ikke lide det. Elsa maalte Afstanden til begge Sider. "Her kan jeg ikke lide at være," sagde hun, "skal vi ikke hellere gaa hen til et større Beskyttelsesrum?" Jeg sagde at det fik vi ikke Lov til. Vi maatte blive, hvor vi var. Selv holdt jeg heller ikke rigtigt 


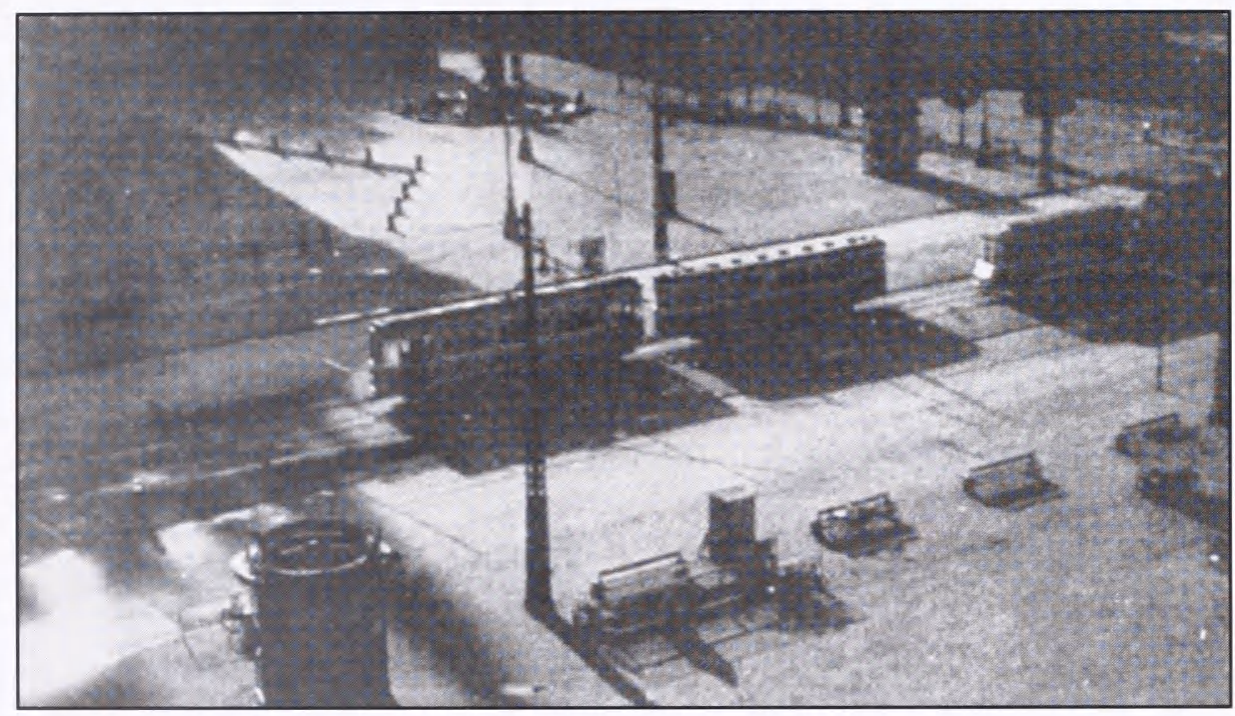

Der er blest natlig luftalarm. Rädhuspladsen i Kobenhavn ligger ode hen i fuldmäne (C. Nash Hendriksen: Den danske Kamp, 1948, s. 116).

af det. Jeg har altid haft en ubehagelig Fornemmelse, naar jeg kommer i snevre Rum, hvilket stammer fra min Barndom, da jeg var indespærret i en Ølvogn i et længere Tidsrum. Men man maa jo beherske sig. Nu kom der atter Lys i vor Nærhed. Adskillige af de andre Mennesker havde et underligt forvirret Udtryk i Ansigtet, men alle sad stille og ventede. Skulde vi mon være her længe? Naar ikke Luftfornyelsesmaskinen var i Gang, blev Luften hurtig tung og trykkende. Rummet er i Modsætning til de almindelige Beskyttelsesrum, ogsaa beregnet til Sikring mod Gasangreb. En Mand hostede. Brandmanden, der betjente Luftfornyelsesapparatet, sagde opmuntrende: "De maa ikke æde saa meget af Luften, saa bliver der ikke noget til os andre." Bare den lille Bemærkning tog noget af det trykkede af Stemningen. Efter at vi havde siddet en halv Snes Minutter kom Befrielsen. Det livsalige enstonige Signal lød og kunde høres tydeligt selv helt her ned i Røret. Folk pilede ud som Rotter af et Hul. En Brandmand tog Tusse paa Skødet og sagde, at hun var vel ikke bange? Tusse kunde ikke faa en Lyd frem, men hun nikkede sandfærdigt med Hovedet. Det var dejligt at komme ud i Regnvejret igen. Paa Vejen mødte vi de andre Kolonifolk, som havde søgt hen til en større Beskyttelseskælder i Nærheden. En Dame havde taget et fremmed Barn med fra Haven. Det havde nok ikke været hyggelige Minutter for Forældrene eller Moderen, der var kommen andet Sted hen med sine andre Børn. Elsa vilde hen i Haven igen. Hun fulgtes med et Par Damer og udvekslede Bemærkninger. De var allesammen mere eller mindre paavirkede af Situationen. Elsa fortalte, at hun havde faaet ondt i Maven. Vi gjorde klart Bord i Lysthuset og begav os saa for Alvor paa Hjemvejen. Tusse betjente sig af et Stykke Legetøj, som hun havde faaet ved Havefesten, og som frembragte en skarp klaprende Lyd. "Hold op!" udbrød Elsa irriteret. Hun havde faaet nok af Lyde for i 
Dag. Det generede hende ogsa at høre Sporvognene sætte sig i Gang. Det lød som Begyndelsen til et Sirenesignal. Da vi var kommen op, faldt der Elsa noget ind. Under Luftalarm standsede Sporvognene jo. Og Passagererne skulde søge Beskyttelsesrum, Sporvognsfolkene selvfølgelig med. Hvad nu med Passagererne, der havde Omstigningsbillet. Blev de 10 Minutter, som Alarmen havde varet, refunderet i Køretiden? Og kunde de i det hele taget komme op igen paa Sporvognen paa en almindelig Billet, hvis de havde en saadan? Jeg lod Spørgsmaalene gaa videre til Næsh paa Politiken. $\mathrm{Nu}$ kan han pille ved dem. Saa snart Tusse var i de hjemlige Omgivelser, faldt hun hurtigt til Ro og legede paa sædvanlig Maade ...

Jeg har glemt at fortælle, at der efter Afblæsningen af Luftalarmen, var en række Ambulanceudrykninger. Jeg tænker mig, at det var til Folk med et svagt Hjerte, maaske har der ogsaa været en eller anden gravid Kvinde imellem, som er bleven saa forskrækket, at hun har skullet føde i Utide. Lidt før 18 Tiden var Elsa nede for at købe ind til Middag. I Grøntforretningen havde der været Diskussion mellem to Damer. Den ene havde sagt, at det ikke var andet end Prøvealarmering, det følte hun sig overbevist om. Hertil svarede den anden Dame indigneret: "Tror De, at man vilde holde mange Tusinde Mennesker for Nar paa den Maade. Saa var det bleven sagt i Forvejen. Jeg var i Roskilde i Gaar, og da maatte vi fem Gange i Kælderen i Løbet af Formiddagen. Det var saadan, saa vi ikke kunde faa Kartoflerne kogt, fordi vi hele Tiden maatte slukke Gassen, som jo ikke maa brænde, mens man er i Kælderen." Hertha kom i Telefonen og snakkede med Elsa. Hun havde talt med en ung Mand, der i Gaar Søndag havde været en Tur i Værløse. I Nærheden af Frederikssundsvejen havde der ligget tre tyske Maski- ner som Vrag. Der er ingen Grund til at tvivle om det, men det viser endnu engang, hvor lidt vi faar at vide. Og i Dag havde hun talt med en Telefonarbejder. Han havde fortalt, at der havde været engelske Flyvere i Eftermiddag, da Alarmen lød, inde over Glostrup. Der havde ligget en Ring af svære tyske Flyvere uden om de engelske. Men der var ikke bleven skudt. Dette maatte være som det var ...

Netop som jeg var ved at sove ringede Næsh. Han fortalte at der havde været Brok med Luftalarmeringen om Eftermiddagen. Den havde været falsk, men var ved et mærkeligt Træk blev[en] rigtig $5 \mathrm{Mi}$ nutter efter. Hvad der ligger bag ved dette, vil nu blive kriminelt undersøgt ...

\section{Juli. (Søndag)}

... Jeg har ikke før vidst, at der var Vagt i Byens Taarne, men det er der. I alle Taarnene sidder der CB Betjente, som skal passe paa, hvis der skulde komme Flyvere. Der holdes Vagt ikke alene om Dagen, men ogsaa om Natten. To Mand i hvert Taarn. De har Telefon og skal med Mellemrum ringe til Stationen, saa at man kan høre at de er levende eller vaagne. Unge Næsh er knyttet til Frederiksberg og ved kun noget nærmere om Forholdene derude, men de er rimeligvis ens over hele Byen. Natten til i Gaar var han for første Gang paa Nattevagt i et Taarn, nemlig i Zologisk Haves store Taarn. Han og Kammeraten var forsynet med en Kikkert og et Kompas, saa at de kunde gøre deres Meldinger mere Præcise. Han havde glemt at faa sin Militærkappe med, [saa] han frøs noget saa Jævelig. Ordren gik ud paa, at han skulde observere Flyvere og eventuelt notere Bombenedslag. Elevatoren er sat ud af Funktion, saa de maatte benytte Trappperne. I løbet af Natten tog han flere Gange Motion ved at løbe op og ned i Taarnet. Derved holdt han 
Varmen. Elevatorstolen er parkeret oppe i Taarnets Spids, saa de kan søge derind og hvile sig. Jeg spurgte, om det ikke opfordrede dem til at hvile sig mere end til at holde Vagt. Dertil svarede han Nej. Det var saa spændende at staa og kigge ud over den sovende By. De lyttede anspændt, men hørte ingen Flyvere. Derimod hørte de flere Gange i Nattens Løb Løverne brøle. Naar de trængte til lidt Oplivelse ringede de til Vagterne i de andre Taarne og udvekslede om ikke Iagttagelser saa dog Morsomheder. Tænderklaprende Morsomheder. Det var forøvrigt hver halve Time, de skulde ringe til Stationen. Saa der er altsaa skrap Kontrol. Paa Grund af den lyse Himmel, var det forholdsvis let at orientere sig i Byen, selv om denne var mørklagt. Men naturligvis, de vidste jo ogsaa i Forvejen Besked, saa der behøvedes ikke mange Kendemærker, før de havde hele Billedet klart. De konstaterede ingen Overtrædelser af Mørklægningsbestemmelserne. Man hørte godt oppe i saadan et Taarn. Hver en Lyd trængte igennem langvejs fra. Saaledes kunde de høre Bilmotorer langt langt borte. Som bekendt er Sverige ikke mørklagt mere. Malmø og Landskrona straalede, og de kunde ogsaa se efter fjernt Glimt af Helsingborg. Fra Hovedbanegaarden kom der sommetider Projektørlys. Det var naar et Tog rangerede. Blandt de Bygninger, som de tydeligt kunde se, var de store Gasbeholdere. Henad Morgenstunden vaagnede Dyrene i Zoologisk Have, først Fuglene. Den ene Stemme fulgte efter den anden, og til sidst var det en hel Symfoni. Den Taarnvagt havde været ham en stor Oplevelse.

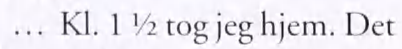

var temmelig overskyet, og som sædvanligt, naar det er Tilfældet, sagde jeg til mig selv:

Det skulde ikke undre mig, om vi [fik] Luftangreb i Nat. Og denne Gang slog det til.
Neppe var jeg kommen indenfor Døren og haft smidt alt Tøjet - Jeg skynder mig altid med at komne i Seng, naar jeg kommer saa sent hjem - før Luftsirenernes forbandede Lyd lod sig høre. Tusse, som ellers næsten ikke er til at kalde til Live om Natten, røg op af Sengen som et Lyn. Til at begynde med var hun noget nervøs, Men det satte sig hurtigt. Tusse tog sin kæreste Dukke samt den ene af Klapstolene og gik selv i Forvejen ned ad Køkkentrappen. Jeg havde haft Vand over til Te. Elsa slukkede for Gassen. Det havde ikke gjort saa meget, selv om hun havde undladt det, for en af Husvagterne drejede om for Hovedhanen. Vi var nogle af de første, der kom ned i Kælderen. De førstankomne havde anbragt sig paa en Bænk midt i Lokalet. Vi slog vore Klapstole op i et Hjørne, et Murhak, der yder særlig god Beskyttelse. Tusse sad paa Skødet hos Elsa med sin Dukke i Armen. Hun var meget rolig, efterhaanden smilende. Folk kom vandrende ned og sagde halvironisk God Dag eller God Morgen. Der var ingen Panikstemning. Sidst kom Lotterikollektricen og hendes Datter. Førstnævnte havde ved forrige Kældergang nægtet at gaa ned, men i Aften var hun ikke saa høj og flot. Det var Skudene, som vi ikke fik nogen af sidst, der havde pillet hende ned. Men hun vilde ikke være vel noget. Hun sagde blot, at hun ikke havde hørt hverken Sirenen, Fløjten i Gaarden, Raabene om at gaa i Kælderen samme Sted eller Husvagtens voldsomme Ringning paa hendes Dør. Men Skudene kunne altsaa gøre det. Det lød heller ikke godt. Først kom der en halv Snes Skud, der aabenbart stammede fra Luftværnskanonerne. Men saa kom der en 3-4 mægtige Brag med dyb Resonnans. Det var saadan, at Murene rystede. Jeg kunde føle det, men overbeviste mig dog først om, hvorvidt det var mig, der var nervøs, hvilket dog ikke var Tilfældet i en saadan Grad, at 


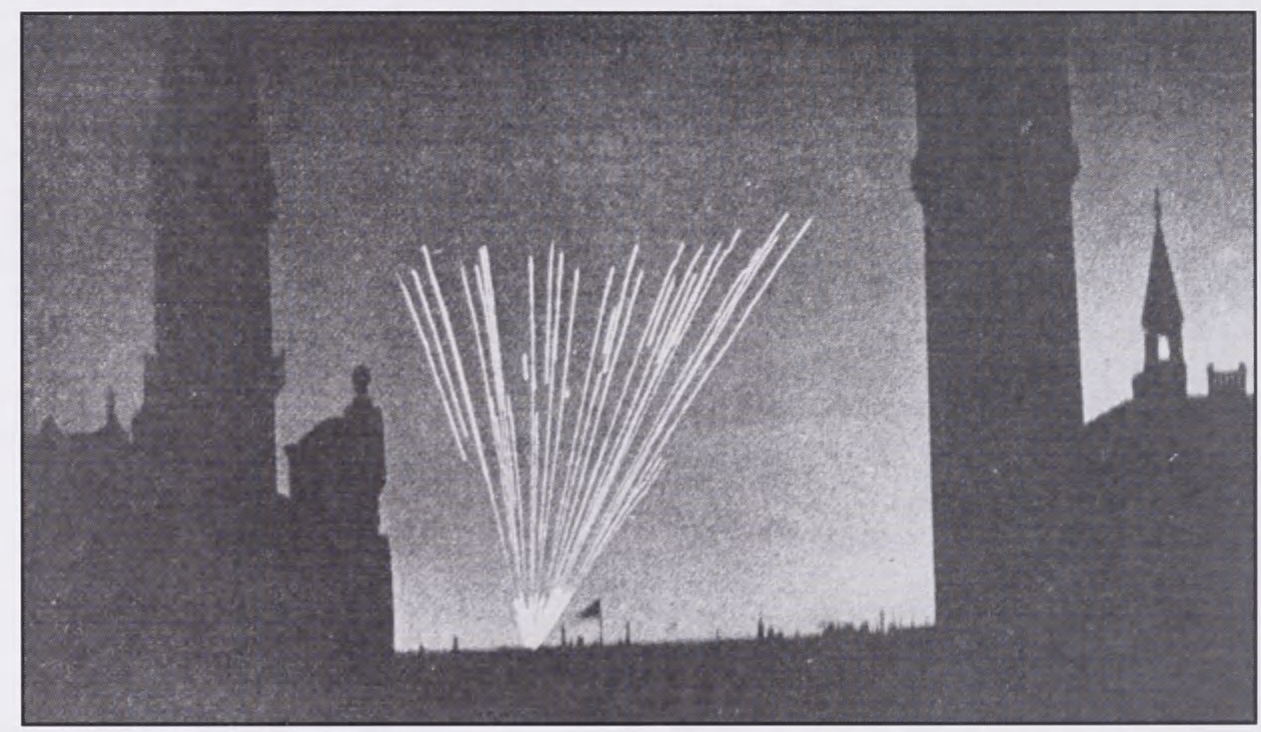

Billede fra Rädhuspladsen i Kobenhavn fra en af de forste natlige luftalarmer. Det tyske antiluftsskyts sporprojektiler virkede som et festfyrvarkeri, men de talrige granatsplinter forairsagde talrige skader og ulykker (C. Nash Hendriksen: Den danske Kamp, 1948, s. 112).

jeg rystede. Der kunde ikke være nogen Tvivl om, at de havde slaaet ned. Og vi blev enige om, at det sikkert maatte være ude paa Refshaleøen, at det gik los. Ind imellem havde Luftværnskanonerne travlt. Der blev ogsaa hørt en Serie Maskingevær-Skydning. Bombardementet stod paa en halv Snes Minutter, tror jeg, saa blev det stille. Saa sad vi i lange Tider og lyttede. Endelig kom dem livsalige Lyd af Afblæsningssignalets lange ensartede Tone. Den er ikke køn, men den lyder saadan. Vi havde da været i Kælderen omkring 3 Kvarter. I en Fart kom vi op ad Trappen. Jeg vilde straks tænde for Gassen under Kedlen. Men der var ingen Gas i Rørene, det kom først i Løbet af en 5 Minutter. Efter at have lavet Te gik jeg i Seng....

\section{Juli.}

Vi sov til Kl. 10 og var ganske udsovet. Jeg skulde ind paa Bladet og hente „Granater.” Forinden talte jeg med Husum paa Berling- ske Tidende. ${ }^{4}$ Han havde endnu ikke faaet at vide, hvad der var sket i Nat. Myndighederne sov. Selv havde han været i Kælderen paa sin Bopæl paa Graabrødretorv, men han havde mærkeligt nok ikke hørt nogen Skydning. Man skulde ligefrem tro, at Manden havde været chokeret, for jeg synes ikke at nogen kan have undgaaet det. Derefter talte jeg med Oskar Petersen paa Ekstrabladet. Han vidste kun, at der havde været en Lysbombe over Ingeniørkasernen paa Østerbro og saa naturligvis en Masse Skydning. To ældre Damer var døde som Følge af Chock. Jeg tog afsted. Solen missede frem engang imellem. Alle Mennesker talte om Bombardementet, men ingen vidste noget. Oppe paa Bladet talte jeg med vores gamle Fotograf Damgaard. ${ }^{5}$ Han bor ude i Gentofte. Han havde set Luftbombardementet, der jo var tilstrækkelig langt borte. Det havde set pragtfuldt ud. En halv Snes Projektører havde gennemsøgt Himlen og krydset Klin- 
ger. Lysbomber havde lyst. Og der var bleven fyret med Projektiler der viste lysende Luftbaner. Derfra tog jeg op paa Gyldendal og fik nogle Skolebøger til Tusse af Kes. Han havde hverken hørt eller set noget. Han bor i Skodsborg, hvor der ikke havde været Luftalarm. Jeg tog videre til min Bogbinder. Hr. Carl Lund var ude, men jeg talte med hans Frue. Hun fortalte, om den urolige Nat, de havde haft. De bor for Tiden i en Havekoloni ved Kløvermarksvejen. Neppe havde Luftsirenerne ladet sig høre, før det begyndte. Fruen og hendes Mand havde ilet hen til et militært Luftbeskyttelsesrum i Nærheden. Det var bleven godt gennemrystet af Bomberne, der jo slog ned ikke saa langt fra. Andre Kolonihavefolk længere ude havde ikke kunnet naa at komme i Beskyttelsesrum. De vil nu ikke længe bo i deres Haver. Fru Lund havde hørt, at der havde været tre engelske Maskiner oppe over Byen. De skulde være kommen fra hver sin Kant saa Tyskerne havde haft Besvær med at finde dem. At der maatte være sket noget ude paa Refshalen følte hun sig overtydet om, eftersom Adgangen der ud til Morgen havde været spærret. Langelinjemolen skulde ogsaa være spærret. Men det kunde jo være, fordi man derfra kan se over til Refshalen, sagde hun. Hun havde hørt, at der var faldet Granatstumper paa Christianshavns Vold og helt hen paa Amager Boulevard. Det kunde dog være, at det var Stumper fra Luftværnskanonernes Projektiler, mente hun....

Som meddelt sad jeg selv med Kone og Barn i Beskyttelsesrummet. Jeg hørte en Række Bump, korte og klare, som kun kunde komme fra Luftværnskanonerne. Desuden hørte jeg Maskingevær Knitren. Men saa kom et dybt Drøn, der ligesom bredte sig i den sidste Ende. Det kunde kun være en Bombe. ${ }^{6}$ Jeg følte en Sitren og mente, at det var mig selv, der rystede af Nervøsi- tet. Jeg saa paa Fingeren. Nej, saa nervøs var jeg alligevel ikke. Saa følte jeg paa Væggen, ja, det var den, der dirrede. Havde jeg haft en Seismograf med i Kælderen, vilde den have svinget ganske voldsomt. Den Virkning kunde en Kanon ikke have paa Jorden og Murene. En Bombe maatte have ramt Jorden. Var den faldet i Vandet kunde der neppe være indtruffet det samme, men mindre den var faldet paa meget lavt Vand. At Bomberne var faldet paa Refshaleøen betragtede jeg som givet, da jeg hørte, at der om Morgenen var bleven foretaget Afspærringer. Det samme gjaldt den nordlige Ende af Frihavnen. Noget maatte der være sket. Jeg talte med Skov, der har Forbindelse med Udenrigsministeriet og der igennem med den tyske Værnemagt. Han havde faaet følgende Forklaring: Der var kun kommen en engelsk Flyvemaskine, og den var kommen op gennem Havnen og havde passeret baade Langebro og Knippelsbro. Og den havde altsaa ikke kastet nogen Bomber, men der var blot bleven skudt efter den. Den havde ved 2 Tiden passeret Broerne, selv var jeg kommen over Knippelsbro ved 1 1/2 Tiden. Hvordan maa jeg havde taget det, hvis jeg pludselig var bleven, overfløjet. Jeg havde vel kastet mig ned og havde indtaget en meget ærbødig Stilling. Heller ikke senere paa Dagen havde jeg faaet noget at vide om de kastede Bomber, men Radioavisen opfordrede til at være agtpaagivende, hvis man skulde se et Hul i Jorden. Det kunde være en tidsindstillet Bombe. Det saa heller ikke meget ud af, at der ikke var sket noget. ...

Ved halvto Tiden, netop som jeg skulde til at gaa hjem begyndte Sirenerne at lyde. Nu kunde jeg altsaa ikke forlade Bygningen, og jeg maatte haabe, at Elsa og Tusse kom godt i Kælderen og ikke kom noget til. Det varede ikke længe, saa begyndte en voldsom Skydning. Det var ude i Retning af 
Kastrup. Tidligere paa Aftenen havde Folk ringet til mig og sagt, at de havde hørt Skydning nordpaa og havde antaget, at det kom fra Værløse Flyveplads. Det var nok dem, der blev bombet. Men jeg kunde naturligvis ikke faa noget at vide. Bombardementet fortsatte ude ad Kastrup til. Der faldt vistnok ogsaa nogle Bomber. Redaktionssekretærerne og jeg gik ikke i Bomberummet, da det var saa lang borte. Ingen af os var helt normale. Det var ligesom om vi havde faaet for højt Blodtryk, men udadtil var vi meget rolige. Ved 2 1/2 Tiden ringede jeg til Brandvæsenet, som havde kørt med en Masse Ambulancer. Med den største Vanskelighed kom jeg til at tale med Manden, som havde lynende travlt. Omsider fortalte han mig, at de havde kørt med ikke færre end 25 chockramte Personer. Umiddelbart efter lød Afvarslingssignalet, den uharmoniske, men dejlige Lyd og jeg skynder mig hjem for at se hvorledes det er gaaet.

... Jeg fik at vide, at alt var gaaet uden særlig Nervøsitet. I Modsætning til de andre Aftener havde Tusse næsten ikke været til at faa op. Der havde været en almindelig Snakken dernede. Det var ligesom om man var kommen ind i en Rutine. I halvanden Time havde Kælderopholdet varet. Tiden havde gaaet langsomt. Kun nogle enkelte Skud havde været at høre. Luften i Kælderen, da man lukkede den ene Dør for Trækken, var en blandet Odeur af Slagterens sure Ben, Kaffehandlerens Kaffe og Osteforretningens Ost. Der kunde være et behageligere Sted at trække Vejret. ...

\section{Juli.}

Vi gik tidligt i Seng i Aftes, idet vi var af den Formening, at vi nok skulde i Kælderen i Løbet af Aftenen.

\section{Juli.}

Jeg vaagnede badet i Sved efter en lummer Nat, hvor jeg ofte havde været vaagen. Ingen Luftalarm, ingen Kældergang, Maanen havde holdt Vagt. ... Mens jeg erindrede det, vil jeg anføre, hvad jeg hørte i Gaar Aftes. Næsh havde gennem nogle CB Betjente, der havde holdt Vagt i Byens Taarne den Nat, da der faldt Bomber paa eller ved Refshalen, faaet at vide, at de havde set to vældige Ildsøjler paa de Kanter, og saadanne Ildsøjler kunde kun stamme fra Bombenedslag. Saa her er altsaa Beviset for, at Tyskerne „er daarligt underrettet " med Hensyn til det Tilfælde.

\section{Juli.}

... Ved 1 Tiden klædte jeg mig af. Jeg var netop ved den sidste Strømpe, da den infame Lyd af Luftsirener lod sig høre. Det var femte Luftalarm her i Byen, den fjerde natlige. Jeg vækkede Elsa, hun sagde, ved en Flod af svovlede Eder. Alle kom i Tøjet, Ritta var nærmest lidt oplivet. Inden hun sov, havde hun sagt: "Bare vi skal i Kælderen i Nat, Mor, det er saa sjov." Hun fik altsaa sit ønske opfyldt. Vi stavrede ned ad Køkkentrappen med vore Klapstole og et Tæppe, iført Overtøj. Allerede paa Vej ned begyndte de at skyde med Luftværnskanonerne. Der kom lidt flere i Kælderen end de foregaaende Gange, men det var hovedsagelig Mænd. Konerne var paa Landet. Det var Græsenkemænd. En af dem saa fuldkommen forvildet ud. En ukendt Dame sad ved Siden af. Ingen kendte hende. Der var ligesom noget mystisk mellem dem. Mon ikke, det var en lille tilfældig Historie. Damen var meget nervøs. Luftalarmen varede tre Kvarter. Der var en kraftig Træk i Kælderen, saa man begyndte at fryse. Hvad saa til Vinter? Men Dørene maa ikke lukkes. Murene kan blive slaaet skæve, og saa kan man ikke faa dem 
op. Ved 2 Tiden laa vi atter i vores Seng.

\section{Juli. Søndag.}

... Vi tog i Haven, hvor vi hos Marketenderen købte Mad og spiste. Elsa talte med Fru Rasmussen overfor. Det stadige Emne er Flyveralarmeringerne. ... Paa Redaktionen havde ingen følt Trang til at gaa i Beskyttelsesrummet, men var bleven oppe. Hvorfor? Næsh mente, at det var fordi Budkonerne sad dernede. Man vilde ikke blande sig mellem dem. Jeg bemærkede, at under saadanne Forhold skulde man gerne være lige. Men Raadhustaarnet skulde bare blive ramt en Gang, saa gik det nok.

Vi slap ikke for at komme i Kælderen. Kl. 23 gik vi i Seng. Jeg mente vi fik Luftalarm, Elsa mente Nej, og havde det ikke været for Anstændighedens Skyld, saa havde vi væddet. Jeg laa i min bedste Søvn Kl. 0.30, da Alarmen kom. Vi kom paa Benene uden større Nervøsitet og kom i Kælderen paa sædvanlig Vis. Vi har snart faaet Rutine. Det er 6. Alarm. Der sad et Jødepar dernede og trykkede sig. Tysklands Haand var over det. Tiden trak ud, og vi hørte ingen Skydning. Efterhaanden vovede adskillige af os op i Gaarden. Der laa ligesom en stivnet Sandflugt af Skyer hen mod Maanen. Et blaat Lys saas udfor flere af Beskyttelsesrummene i den store Karregaard. Der blev talt halvhøjt i Hjørnerne, hvor Folk udvekslede Betragtninger. En Husvagt med Armbind gik rundt og forsøgte at være morsom. Først efter $2 \frac{1}{2} 2$ Times Forløb blev der blæst af. Det er den længste Alarm, vi har haft her i Byen. Jeg var bleven sulten og fik et Stykke Mad og en Kop Kaffe. Tusse saa bleg ud af Mangel paa Søvn. Hun havde haft lidt Mavekneb nede i Kælderen, men ellers var Humøret meget godt. Jeg gik ind i Herreværelset og saa ned paa Gaden. Der var mange Cyklister med mørklagte Lygter. De havde været spærret inde rundt om og var nu paa Vej hjem. Klokken var tre. Normalt var det langt over Sporvognstid, men de kørte ustandselig fra de Steder paa Linien, hvor de havde været parkeret. Saa gik jeg i Seng og slukkede Lyset. Gid Fanden havde det hele.

\section{Juli.}

... Efter at have ordnet mine private Job tog jeg paa Bladet. Jeg havde Hovedpine og købte engelske Albyler. Paa Bladet var der en Masse Luftværnsstof. ... Nielsen været paa Besøg her oppe paa Bladet. Han fortalte, at Farten mellem Helsingør og Helsingborg var afbrudt, hvilket formentlig var ensbetydende med, at Englænderne havde lagt Miner ud i Løbet af Natten, ligesom de havde gjort i Sundet den foregaaende Nat, hvilket havde haft til Følge at en svensk Damper var bleven minesprængt. ${ }^{8}$ Endvidere fortalte Nielsen mig, at der i Løbet af Dagen havde været en engelsk "Speedfire" inde over Landskrona, hvor man havde sendt den tre Varselsskud. Derefter var den forsvunden over Sundet mod Danmark. At denne lille Jagermaskine funktionerer saa langt fra England lader formode, at der findes et engelsk Moderskib et Sted i Kattegat.

$$
\text { ... Jeg lavede Te og kunde ikke }
$$

rigtigt beslutte mig til at gaa i Seng, for jeg var jo overbevist om, at jeg skulde op. Naa, jeg dumpede i Kassen alligevel. Klokken var vel da 0.30. Klokken 2 1/2 eller der omkring lød Flyveralarmen, men lidt Hvile havde jeg da faaet. Paa efterhaanden trænet Vis kom vi i Kælderen. Der skete en Pudsighed undervejs. I Karavanen ned ad Kældertrappen havde vi foran os Jøden og hans Kone. Derefter kom Abel og hans Kone eller rettere sagt omvendt. Det er Folkene nedenunder os. Pludselig hørte vi Jødinden med sin Akcent udbryde: "En Rotte, en Rotte!" Rot- 
ten, en stor Kammerat, var landet paa hendes ene Fod og var saa sprunget videre. Hun rystede sin Pyjamas for det Tilfælde at det var den Vej, den var sprunget. Derefter begyndte hun at rable en hel Del af sig til Manden vistnok paa Jiddisch. Abel blev tilbage ved Udgangen til Gaarden, hvis Dør han holdt aaben. Han sagde, at det var for at Rotten kunde smutte ud, men jeg havde nærmest Indtrykket af, at det var for han paa en hurtig og let Maade kunde flygte, hvis Rotten skulde komme mod ham. Jeg gik videre. Det samme gjorde Elsa, som ikke er det mindste bange for Rotter. Hun synes tvært imod, at de har saadan kloge Øjne. Heller ikke Ritta er bange. Husvagten gik rundt med sin blaa Lygte i Krogene. Den havde bragt sig i Sikkerhed. Vi anbragt os i Kælderen. Pludselig sagde Fru Abel: ”Jeg maa vist gaa op og hente min Mand. Han er saa bange for Rotter." Lidt efter kom hun slæbende med ham. Saaledes er der adskillige Morsomheder man oplever selv under de Forhold. Vi sad i vores sædvanlige Krog, Familien Abel og Familien Bergstrøm. Vi har faaet Ejendomsret paa den. Enhver har efterhaanden faaet sin Plads. Der hørtes ikke et Skud. Vi havde kun siddet i 10 Minutter á et Kvarter, da Afblæsningen lød. Og glade strømmede vi op igen. Vi kiggede ud gennem Vinduet til Gaden. Klokken var henad tre. Der var begyndt at komme en lysere Tone over Himlen. Adskillige Mennesker ilede afsted, til Fods og paa Cykel. Derimod var der ingen Sporvogne. De var kommen i Remise inden Luftalarmen. Der kom et skarpt Glimt i nogle Ruder. Det kom ude fra Dragør Kanten. Men ingen Bulder. Mon Alarmen skulde være blæst af for tidligt? Naa, vi gik i Seng og sov snart udmærket. Bare man gør, hvad man skal, saa maa der ske, hvad der vil. Apropos, det var den syvende Alarm, den sjette om Natten.

\section{Juli.}

... Oppe paa Bladet snakkede jeg med Priemé. Han sagde, at Minister Yde havde betroet Bladet, at der meget snart vilde komme en anden Ordning med Hensyn til Luftalarmen. ' Saaledes vilde der ikke mere komme til at lyde Alarm, hvis en enkelt engelsk Maskine gik over Byen. Jeg talte med Luftværnschefen, Politiinspektør Dahl om det. Han indrømmede, at man arbejdede paa en saadan Ordning, men at der vel nok vilde gaa nogle Dage, inden den vilde blive ført ud i Livet. Jeg talte med en Politimand $\mathrm{NN}$, son vidste Besked med den foregaaende Nats Vagttjeneste. Politikommissær DahlJensen, Lederen paa Kommandoposten, var om Natten gaaet ud og drikke Sjusser. Overbetjenten havde forespurgt, hvorledes hans skulde forholde sig. Der var jo varslet Flyvere

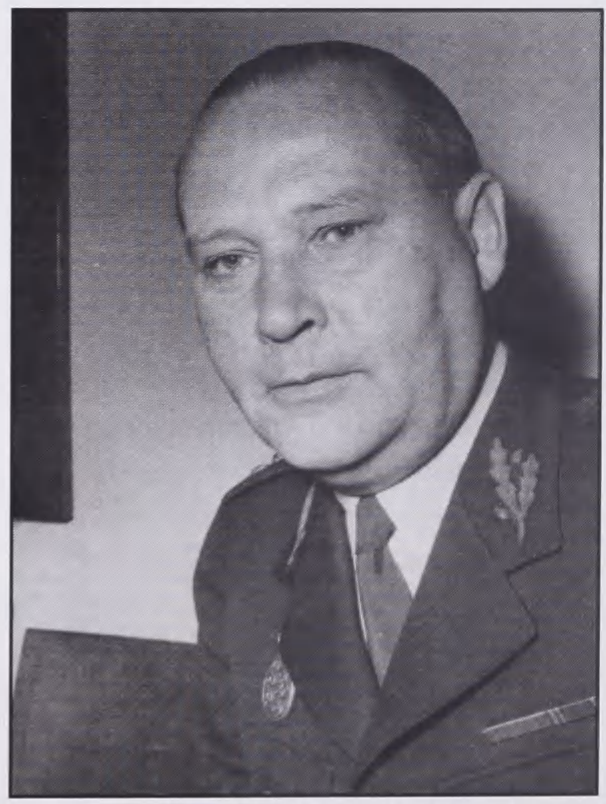

Luftuornschefen i Kobenhavn, Th. Dahl-Jensen, var ude at drikke sjusser, mens en overbetjent morede sig med at varsle luftalarm over Storkobenhavn. Varslingen bragte straks luftvarnschefen tilbage på sin post. 


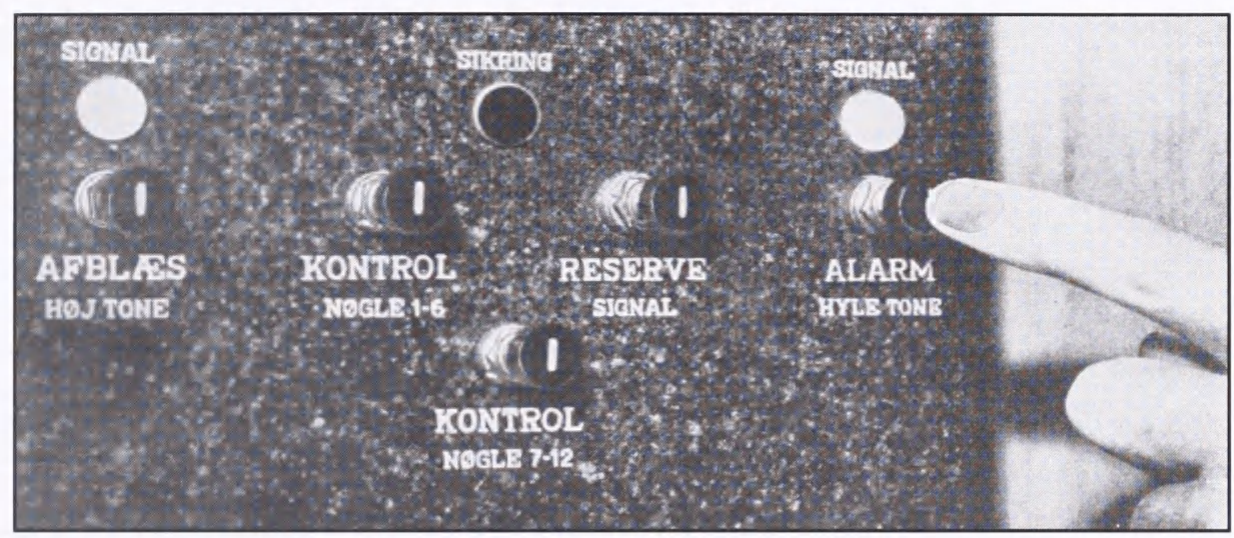

Et nerbillede af den instrumenttavle, der varslede luftalarm over Storkobenhavn. Til hojre alarmknappen, til venstre knappen med afblesningstonen. Det var forstnavnte knap en overbetjent for sjov kl. 2 om natten den 22. juli 1940 trykkede på i vicepolitiinspektor og luftvarnschefi Kobenhavn Th. Dahl-Jensens fravar og derved uden grund jog hele den storkobenhavnske befoldning $i$ beskyttelsesrum (Hvem Hvad Hvor 1941, s. 285).

for Sjælland. Dertil havde Dahl-Jensen bare sagt, at han maatte handle efter Konduite. Uden særlig Grund havde Overbetjenten trykket paa Knappen ved 2 Tiden og havde jaget hele København i Kælderen. Samtidig havde han jaget sin Chef tilbage til sin Post. Man sagde for Spøg, at det var derfor han havde trykket. Muligvis var det dette alt for tilfældige man nu vilde til Livs ved et $\mathrm{Nyt}$ Reglement om Varsling. Senere talte jeg med Dahl-Jensen, dog ikke om Alarmeringen.

Det var ham, der ringede op. Han sagde, at der var flere Mennesker, som havde beklaget sig over det Billede, Politiken forleden Dag havde bragt af Raadhuspladsen under Luftalarm med en Vifte af lysende Streger i Baggrunden. (Se omstaaende Billede). Folk syntes ikke, at Bladet skulde have Lov til at bringe den Slags forfalskede Billeder. Jeg sagde, at jeg vidste ikke noget nærmere om Fotografiet, men da jeg saa Bladet om Morgenen havde jeg tænkt: Hvad skal det være? Det ligner jo ikke noget videre Projektørlys. Jeg havde slaaet mig til Ro med, at det skul- de det nok være alligevel, og at der forelaa en grov Retouche. Men jeg lovede at skaffe noget at vide om Tingene. Priemé fortalte mig, at Fotograf Petersen havde eksponeret Billedet i 10 Sekunder, det var derfor at der var fremkommen de lysende Streger, som alle stammede fra særlige Projektiler. Mellem hver af de lysende Projektiler laa der fem mørke. Der var altsaa i Løbet af de 10 Sekunder bleven affyret et halvt Hundrede Skud mod den engelske Maskine. Kanonen stod et Sted paa Amager, men ikke der, hvor man kunde regne sig til det af Billedet. Billedet var nemlig bleven censureret af de tyske Myndigheder, som ikke havde haft noget imod at vi bragte det, naar blot der blev lavet en lille Kunst. Denne var bleven foretaget af Alfred Olsen. Han havde klippet Lysviften ud og havde anbragt den Halvanden Centimeter længere til venstre i Billedet. Samtidig havde han klippet den nederste Spids af Ildviften af. To Ting var naaet. Ved Flytningen var „Kanonens Stilling “ kommen længere nordpaa. Ved Afklipningen af Spid- 


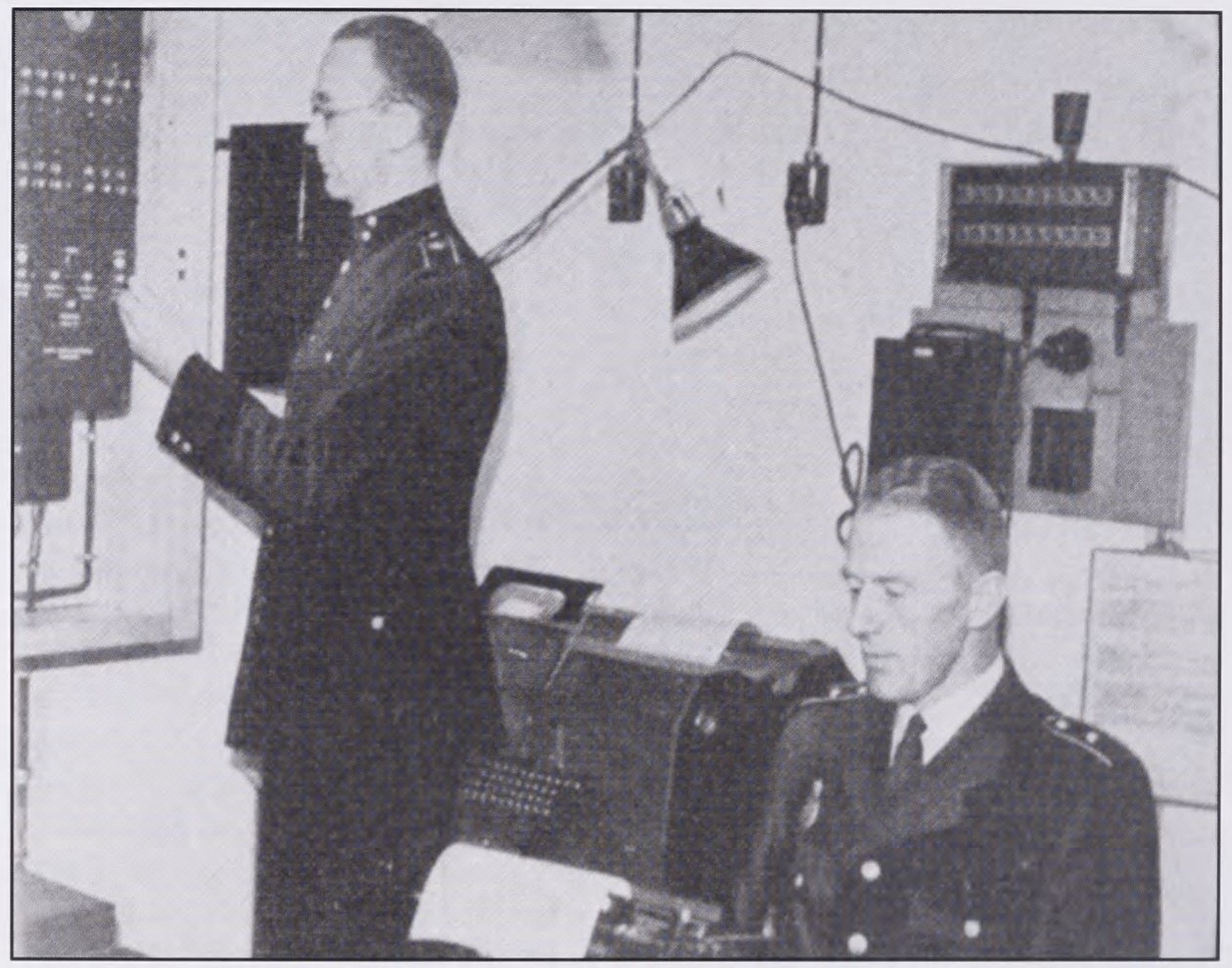

Billede fra Statens civile Luftvarns kommandocentral i Kobenhavn. Den vagthavende overbetjent stair med fingeren på den knap, der fik sirenerne i Storkobenhavn til at lyde. Et enkelt tryk var nok til at fä en lille million mennesker ud af sengene og i beskyttelsesrum (Hvem Hvad Hvor 1941, s. 285).

sen var den bleven flyttet meget længere tilbage i Billedet, altsaa østpaa. Hvis Englænderne fik fat i Billedet vilde de ikke af det kunde finde Batteriets Stilling. Saa megen Omtanke anvendes der overfor de mindste Ting....

\section{Juli.}

... Jeg tog ind paa Bladet i god Tid og klippede. Derefter talte jeg med Politikomissær Dahl-Jensen om et Billede fra Kommandoposten paa Politigaarden, hvorfra Luftalarmerne bliver udsendt. Det vil jo nok interessere Publikum at stifte nærmere Bekendtskab med Urostifteren. ...
Hen paa Eftermiddagen blev jeg saa sammen med en Fotograf inviteret af DahlJensen til at se det civile Luftværns Kommandorum. Jeg tog Tage Christensen med. ${ }^{10}$ Han var meget interesseret. Først fik vi et lille Kursus oppe paa Kontoret af DahlJensens i Meldetjeneste. Det viste sig, at der var udbygget et meget fint Net af „Meldemænd" anbragt rundt om i alle Taarne. Et særligt vigtigt Afsnit var Amager bleven. Korpset der var flere Gange bleven forstærket. Det civile Luftværn stod i Forbindelse med den tyske Luftværnstjeneste, hvis Hoveddomicil er Telefoncentralen paa Nørregade, hvor der er indrettet en særlig 
sikret Kælder. Herfra modtager det civile Luftværn de fornødne Direktiver. Men det hjælper ogsaa med Efterretningstjenesten. Der var slaaet forskellige Cirkler paa et Kort. Saa snart en engelsk Maskine havde overskredet Cirklen, som passerede Lolland Falster, blev der givet Forvarsel. Det civile Luftværn underrettede saa en Masse Institutioner bl.a. Hospitalerne, som traf de fornødne Forholdsregler. Paa en Afstand af 4 Mil blev der givet Alarm. Det civile Luftværn maatte kun selvstændig give Alarm, i det Tilfælde at København blev angrebet. Næsten hver Nat havde der været Meldinger i den senere Tid, men det var gledet over. Refshaleøen var beskyttet med Spærreild, men ellers vidste man intet. Ved at trykke paa en Knap blev 136 Sirener mekanisk sat i Funktion. Det blev ikke helt paa samme Tid paa Grund af den ohmske Lov. ... Det var en fantastisk Tanke, at et lille Tryk paa Knappen kunde jage en Million Mennesker i det storkøbenhavnske Luftbeskyttelsesrum i Kælderen, mens Afblæsningsknappen kunde kalde dem op igen. En grov Spøg tør man sige....

\section{Juli. (Mandag)}

... Jeg sad i Formiddags og ordnede mine Udklip, da jeg pludselig gjorde en ærgerlig Bevægelse. En Sporvogn i Start havde givet en Lyd fra sig, som mindede om Optrækket til et Sirenehyl. Jeg var halvt underbevidst bleven irriteret af en Forestilling om, at nu skulde man i Kælderen. Paa samme Maade med Sireneprøven hver Morgen Klokken præcis 9. Jeg er ikke alene om at spidse Øren, hele Byen gør det. Og det sker paa hver Time af Dagen. De mange natlige „Kældergange" har gjort et uudsletteligt Indtryk. Jeg har vist kun skrevet om det en enkelt Gang før. I og for sig skulde jeg anføre det hver Dag i mit Referat, for man kan ikke vænne sig til det. Ikke fordi man er ængstelig, men som sagt fordi de ærgrer en.

... Ved $2 \frac{1}{2}$ Tiden vaagnede jeg ved, at Elsa stak mig en spids Albue ind i Siden. „De skyder!“ sagde hun. Det var rigtigt nok, Der kom en hel Serie Skud. Vi troede, at vi havde overhørt Sirenerne og skyndte os i Tøjet. Vi trak det tildels paa ude i Korridoren, for man kunde jo ikke være sikker paa, at der ikke kom et Sprængstykke ind gennem Vinduet. Efter at have slukket Lyset gik vi ud paa Altanen til Gaarden. Det var Maaneskin, men skyet. Et Projektørstribe viste skraat op over vort Hus. Den havde fat i en Flyvemaskine. Der var mørkt i Tilflugtsrummene, men der kom smaa Lysglimt fra Lejlighederne rundt om. Folk var oppe som vi. Vi kunde ogsaa høre dem baade ovenover og nedenunder. Folk kunde aabenbart ikke forstaa, hvorfor Sirenerne ikke lød. Men jeg var klar over det. Det var den nye Ordning med ikke at alarmere, hvis der kun var en enkelt Flyvemaskine. Man maatte imidlertid være bleven klar over, at der maatte være flere, for pludselig satte Sirenerne i, og nu blev uroen tydeligere i hele Huset. Samtidig kom der en ny Serie Skud. Og de var nærmere end den første Serie, altsaa fra et andet Batteri. Elsa mente at have hørt et Par af de dybtklingende Skrald, som sikkert var Bombenedslag, jeg bemærkede dem ikke. Husvagten i vores Opgang var aabenbart ikke hjemme, for der blev ikke ringet paa Døren som ellers. Vi skyndte os ned ad Trappen til Kælderen med vores Klapstol. Vor Nabo Nyborgs var kommen hjem fra Ferie og havde anbragt sig i vores Krog, hvor vi før har siddet sammen med Abels. Da Fru Abel kom ned, blev hun lidt forvildet over at se sin Plads optaget. Hun satte sig saa overfor sammen med sin Mand og sine to voksne Drenge. Alle var forbavset over, at Sirenen var kommen saa meget bagefter. Jeg fortalte om den nye Ordning. Udenfor var der stadig Serieskydning. 
Fru Nyborg snakkede med, men hendes Mand, der er meget ung og genert - storsnudet, Fuldmægtig i et Ministerium, kunde ikke være med. ${ }^{11}$ Alarmeringen varede en lille halv Timestid, saa kunde vi atter tage vore Pakkenilliker og gaa op. Man bliver trængende for noget efter saadan en Ekspedition, men Elsa var ganske utilbøjelig til at lave Kaffe. Efter at have kigget ned paa Gaden, hvor en enlig Cyklist, der maaske havde siddet i en muggen Dækningsgrav, skyndte sig hjemad med den lille blaa Gnist af en Lygte foran. Saaledes forløb den ottende københavnske Alarmering for os.

Noter

Familien Bergstrøm boede Amagerbrogade 20.

2 Ernst Priemé, redaktionssekretær ved Politiken.

3 "Stadil" var en restaurant på Rådhuspladsen.

4 Christian Husum, kriminalreporter ved Berlingske Tidende.

5 Holger Damgaard, ansat ved Politiken 1908 som Danmarks første pressefotograf.

\section{Juli.}

... Paa Bladet spildte jeg en Masse Tid paa et Sprængstykke Fotografi. Det fandtes i Berlingske Aften, og vi beskyldte som jeg senere hørte uretfærdigt Politikommissær Dahl-Jensen for at føre os bag Lyset. Jeg gav ham senere en ordentlig Omgang. Fortjente han den ikke ved den Lejlighed, fortjente han den ved en tidligere. Vi snakkede iøvrigt om der sene Alarmering Natten i Forvejen. Han sagde, at det var vores egen Skyld. Vi havde ikke ønsket saa hyppige Alarmeringer, naar der kun var en enkelt Maskine, og derfor var der bleven alarmeret senere. Han raadede til at gaa i Kælderen saa snart Skydning begyndte. ...

6 Der var ikke tale om en bombe.

7 Alfred Olsen var tegner ved Politiken.

8 Den svenske damper "Grethe" blev minesprængt sydøst for Drogden fyr. En blev dræbt, og to såret.

9 Marinus Yde var generalkonsul i Hamborg, fra 1940 med titlen befuldmægtiget minister.

10 Tage Christensen var fotograf ved Politiken.

11 Fuldmægtig E. Nyborg.

12 Der var ikke noget bombardement. 